\title{
Penilaian Kinerja Menggunakan Metode Balanced Scorecard Pada Perusahaan Sektor Farmasi Sebelum dan Semasa Covid (2019-2020) yang Terdaftar di BEI
}

\author{
Samuel Armando Sagala1, Valentine Siagian² \\ ${ }^{1,2}$ Universitas Advent Indonesia \\ e-mail: 1832169@unai.edu,valentine@unai.edu

\begin{tabular}{ccc} 
Diterima & Direvisi & Disetujui \\
$29-08-2021$ & $13-09-2021$ & $14-09-2021$ \\
\hline
\end{tabular}

\begin{abstract}
Abstrak - Penilaian kinerja perusahaan sangat membantu manajemen dalam menilai sejauh mana yang telah dilakukan perusahaan dalam pencapaian strategi dan visi misi perusahaan. Kinerja perusahaan dapat dinilai menggunakan metode balanced scorecard dimana metode ini menggunakan empat perspektif untuk menilai kinerja perusahaan yaitu perspektif keuangan, perspektif pelanggan, perspektif internal bisnis, dan juga perspektif pembelajaran dan pertumbuhan. Metode balanced scorecard tidak hanya menilai aspek keuangannya saja tetapi juga aspek non-keuangan. Tujuan dari penelitian ini adalah untuk menilai kinerja perusahaan sebelum dan semasa terjadinya pandemi covid 19 dengan metode balanced scorecard pada perusahaan yang bergerak di sub sektor farmasi yang terdaftar di Bursa Efek Indonesia (BEI). Penelitian ini menggunakan data sekunder yaitu laporan keuangan dan laporan tahunan enam perusahaan sub sektor farmasi tahun 2019 dan 2020. Berdasarkan pengolahan data hasil menunjukkan bahwa dari empat perspektif yang digunakan, perspektif keuangan mengalami peningkatan karena banyaknya kebutuhan akan obat-obatan dan alat medis sehingga peluang perusahaan untuk mengoptimalkan penjualan produknya. Pada perspektif pelanggan hasil yang didapat menunjukkan peningkatan karena produk yang diproduksi dapat dirasakan manfaatnya oleh konsumen sehingga penghargaan yang didapat juga semakin banyak. Perspektif internal bisnis didapati penurunan pencapaian karena sulitnya perusahaan membuat produk baru dimasa pandemi covid 19 dan lebih berfokus kepada penyediaan alat kesehatan dan juga produksi vaksin. Pada perspektif pembelajaran dan pertumbuhan mengalami penurunan dikarenakan sulitnya perusahaan melakukan pelatihan secara tatap muka sehingga kesulitan untuk memaksimalkan pelatihan karyawan.
\end{abstract}

Kata Kunci: Balanced Scorecard, Penilaian Kinerja,

\begin{abstract}
Performance appraisal is a helpful tools for management in assessing the company's performance Company performance can be assessed using the balanced scorecard method where this method uses four perspectives, namely financial perspective, customer perspective, internal business perspective, and also learning and growth perspective. The balanced scorecard method assesses not only financial aspects but also non-financial aspects, namely customer satisfaction, product innovation and employee capabilities. The purpose of this study was to assess the company's performance before and during the COVID-19 pandemic using the balanced scorecard method in companies listed in the pharmaceutical sub-sector and listed on the IDX. This study uses secondary data, namely financial statements and annual reports of 6 pharmaceutical sub-sector companies in 2019 and 2020. The results of the study stated that from the four perspectives used, the financial perspective has increased due to the large need for drugs and medical devices so that the company's opportunity to optimize product sales. From the customer perspective, the result shows an increase because the products can be felt by consumers so that the companies got more awards. From an internal business perspective, there was a decline in achievement due to the difficulty of the company in making new products during the COVID-19 pandemic and focusing more on the provision of medical devices and also the production of vaccines. In the learning and growth perspective, it has decreased due to the difficulty of companies conducting face-to-face training so that it is difficult to maximize employee training.
\end{abstract}

Keywords : Balanced Scorecard, Performance Assesment 


\section{PENDAHULUAN}

Pandemi covid 19 berdampak ke berbagai hal khususnya berbagai bisnis yang ada di Indonesia. Menurut badan pusat statistik, pemerintah Indonesia sedang mengalami penurunan pertumbuhan ekonomi pada tahun 2020 sebesar 2,07\%. Pandemi covid 19 menyebabkan banyak perusahaan dipaksa untuk tutup, masyarakat kehilangan pekerjaan, penurunan harga komoditas, dan menurunnya daya beli masyarakat. Ditengah pandemi dan ketatnya persaingan di pasar, perusahaan-perusahaan yang ada di Indonesisa juga dituntut untuk dapat membantu dalam meningkatkan pertumbuhan ekonomi dengan cara memaksimalkan sumber daya yang ada, berinovasi, membantu UMKM yang ada di Indonesia dan meningkatkan performa perusahaan melalui perbaikan kinerja pihak pihak internal perusahaan.

Pemerintah mengusahakan berbagai cara untuk dapat memulihkan ekonomi di Indonesia dari kemerosotan ekonomi yang disebabkan oleh pandemi covid 19, salah satu cara yang dilakukan adalah melakukan vaksinasi covid 19 , penyediaan alat alat kesehatan dalam menghadapi pandemi dan diharapkan vaksinasi dapat dilakukan secepat mungkin mencapai $70 \%$ penduduk Indonesia agar dampak pandemi covid 19 dapat diminimalisir dan diharapkan dapat segera berakhir. Perusahaan yang sangat berperan penting untuk mendorong percepatan vaksinasi di masa pandemi ini adalah perusahaan yang bergerak di sub sektor farmasi yang dengan penyediaan obat obatan dan alat kesehatan dapat membantu pandemi covid 19 dapat berakhir.

Pertumbuhan bisnis industri yang disampaikan oleh Kementrian Industri Republik Indonesia pada tahun 2015 yaitu 15,9\% dan menurun sampai ke tahun 2019 yaitu 9\%, yang artinya kinerja perusahaan sektor farmasi mengalami penurunan. Salah satu hal yang dapat dilakukan untuk memperbaiki kinerja perusahaan adalah melakukan penilaian kinerja.

Secara umum manfaat penilaian kinerja adalah mengelola organisasi secara efisien dan efektif, menaambil keputusan dalam memberikan penghargaan, penyesuaian posisi, pegawai.

Kinerja

Menurut Amstrong dan baron (Fahmi, 2017) kinerja adalah hasil yang diperoleh organisasi baik orientasinya profit maupun non profit dalam satu periode tertentu. Menurut (Afandi, 2018) Kinerja adalah hasil kerja yang dicapai oleh perorangan maupun kelompok dalam suatu perusahaan sesuai dengan tangggung jawab masing-masing. kinerja adalah pencapaian pelaksanaan kegiatan dalam mewujudkan visi,misi,dan tujuan organisasi. Kesimpulan berdasarkan refrensi mengatakan bahwa kinerja perusahaan adalah hasil yang dicapai oleh seseorang maupun sekelompk orang dalam satu organisasi dengan menyelesaikan tanggung jawab yang telah diberikan perusahaan.

\section{Penilaian Kinerja}

Menurut (Kasmir, 2016) penilaian kinerja adalah proses menilai kinerja pegawai secara keseluruhan yang telah dilakukan dalam satu periode perusahaan tersebut. Menurut (Hartantik, 2014) penilaian kinerja adalah suatu cara untuk mengevaluasi potensi, kontribusi, prestasi pegawai dalam suatu organisasi yang landasannya adalah untuk pengembangan. Kesimpulan berdasarkan referensi bahwa penilaian kinerja adalah menilai sejauh mana kinerja atau pencapaian yang didapat perusahaan yang landasannya untuk melihat perkembangan pegawai dan perkembangan perusahaan.

\section{Tujuan Penilaian Kinerja}

Menurut (Kasmir, 2016) tujuan penilaian kinerja adalah untuk memperbaiki kualitas pekerjaan, menyesuaikan kemampuan karyawan dengan posisi pekerjaanya,menentukan jenjang karier seseorang, kebutuhan pelatihan dan pengembangan, kepentingan kompensasi, data kemampuan dan skill pegawai, melihat komunikasi antara atasan dan bawahan, tercipta budaya kerja yang baik. Menurut (Zainal, 2015) tujuan penilaian kinerja adalah untuk mengetahui prestasi karyawan, meningkatkan motivasi karyawan dalam bekerja, membantu karyawan untuk lebih inisiatif dalam memperbaiki kinerja. Menurut (Sedarmayanti, 2010) tujuan dari penilaian kinerja adalah untuk mengetahui kondisi organisasi secara keseluruhan, mengetahui kemampuan karyawan, menciptakan hubungan timbal balik antara atasan dan bawahan. Kesimpulan berdasarkan referensi di atas, tujuan penilaian kinerja adalah mengetahui kondisi perusahaan berdasarkan hasil kinerja para pegawai yang bekerja dan hasil penilaiannya dapat dijadikan perbaikan kinerja perusahaan dan juga perbaikan kinerja pegawai.

\section{Balanced Scorecard}

Menurut (Luis dan Biromo, 2007) balanced scorecard alat manajemen yang dapat membantu perusahaan dalam menerjemahkan visi dan misi kedalam aksi.Menurut (Atkinson et.al 2012) balanced scorecard mampu mengukur kinerja organiasi berdasarkan perspektif yang berasal dari visi, strategi sebuah organisasi.

(Kaplan \& Norton, 2000) menjelaskan bahwa balanced scorecard meliputi empat perspektif :

1. Perspektif Keuangan. Perspektif ini berfokus bagaimana kemampuan perusahaan dalam menghasilkan laba dan bagaimana agar laporan keuangan perusahaan dianggap baik oleh pemegang saham

2. Perspektif Pelanggan. Perspektif ini berfokus bagaimana pandangan pelanggan terhdap 
produk dan pelayanan yang dihasilkan perusahaan

3. Perspektif Internal Bisnis. Perspektif ini berfokus kepada bagaimana perusahaan mampu mempertahankan segmen pasar dan pelanggan dari inovasi-inovasi produk baru yang dihasilkan oleh perusahaan.

4. Perspektif Pertumbuhan dan Pembelajaran. Perspektif ini berfokus kepada kemampuan perusahaan dalam mempertahankan sumber daya manusia yang ada didalam perusahaannya agar mampu dalam melakukan tugas dan tanggung jawabnya dengan baik.

Dari keempat perspektif yang dijelaskan menunjukkan bahwa metode balanced scorecard berfokus pada perspektif keuangan dan non keuangan (Mulyadi, 2009)

Berdasarkan pemaparan diatas maka peneliti akan menilai kinerja perusahaan yang bergerak di sub sektor farmasi sebelum covid menggunakan laporan tahunan perusahaan tahun 2019 dan semasa covid mengunakan laporan tahunan perusahaan 2020 menggunakan metode balanced scorecard dengan empat perspektif yaitu perspektif keuangan,perspektif pelanggan,perspektif internal bisnis, dan perspektif pertumbuhan dan pembelajaran.

\section{METODE PENELITIAN}

Penelitian ini menggunakan metode kuantitatif dimana perusahaan sub sektor farmasi dijadikan objek penelitian. Data yang digunakan adalah data sekunder yaitu dari laporan keuangan perusahaan dan laporan buku tahunan perusahaan yang di dapatkan dari website setiap perusahaan dan website BEI. Terdapat 12 perusahaan farmasi yang terdaftar di BEI namun Peneliti hanya mengambil enam perusahaan sebagai sampel penelitian yang sudah mengeluarkan laporan keuangan dan laporan tahunan perusahaan pada saat penelitian ini dilakukan yaitu:perusahaan Indofarma, Kalbe farma, Kimia Farma, Phapros, Tempo Scan,dan Sidomuncul.

Adapun tolak ukur setiap perspektif adalah

1. Perspektif Keuangan

a. Return on Asset (ROA)

$$
\mathrm{ROA}=\frac{\text { Laba bersih }}{\text { Total Aktiva }} \quad \mathrm{x} 100 \%
$$

b. Return on Equity (ROE)

$$
\mathrm{ROE}=\frac{\text { Laba besih }}{\text { Total ekuitas }} \times 100 \%
$$

c. Kenaikan Pertumbuhan dan Pendapatan Pendapatan periode sekarangPendapatan periode lalu

$$
\begin{aligned}
& =\quad \times 100 \% \\
& \text { Pendapatan periode lalu }
\end{aligned}
$$

d. Kenaikan pertumbuhan Laba Bersih
Laba bersih periode sekarang-

Laba bersih periode lalu

$$
=\frac{\text { Laba bersih periode lalu }}{\text { L }} 100 \%
$$

e. Kenaikan Pertumbuhan Biaya Operasi Biaya operasi periode sekarangbiaya operasi periode lalu

$$
=\frac{}{\text { Biaya operasi periode lalu }} \times 100 \%
$$

2. Perspektif Pelanggan

Apabila Perolehan Penghargaan dari pihak eksternal perusahaan meningkat dari tahun 2019 ke tahun 2020 maka hal itu merefleksikan kepuasan pelanggan terhadap produk dan pelayanan perusahaan dan sebaliknya.

3. Perspektif Internal Bisnis

Apabila jumlah produk baru yang dihasilkan perusahaan pada tahun 2019 ke tahun 2020 meningkat makan hal itu merefleksikan kemampuan perusahaan dalam berinovasi dan sebaliknya.

4. Perspektif Pertumbuhan Dan Pembelajaran

Pada perspektif ini apabila jumlah biaya pelatihan yang dikeluarkan perusahaan meningkat dari tahun 2019 ke tahun 2020 itu menunjukkan bahwa perusahaan ingin mempertahankan kompetensi sumber daya manusia di perusahaan tersebut dan sebaliknya.

\section{HASIL DAN PEMBAHASAN}

Perspektif Keuangan

Perspektif keuangan menilai kinerja keuangan perusahaan menggunakan 5 tolak ukur untuk mengetahui kemampuan perusahaan dalam menghasilkan laporan keuangan yang baik bagi pemegang saham.

Tabel 1. Perhitungan rata-rata ROA

\begin{tabular}{lcc}
\hline & $\begin{array}{c}\text { ROA } \\
(2019) \\
(\%)\end{array}$ & $\begin{array}{c}\text { ROA } \\
(2020) \\
(\%)\end{array}$ \\
\hline Indofarma & 0,058 & 0,002 \\
\hline Kalbe Farma & 12,522 & 12,407 \\
\hline Kimia Farma & 0,087 & 0,116 \\
\hline Sidomuncul & 22,884 & 24,263 \\
\hline Tempo Scan & 7,108 & 9,165 \\
\hline Phapros & 4,880 & 2,540 \\
\hline Rata-rata & $7,923 \%$ & $8,082 \%$ \\
\hline
\end{tabular}

Sumber : Data Diolah

Tabel 2. Rata-rata Perspektif Keuangan

\begin{tabular}{llll}
\hline Tolak Ukur & $\begin{array}{l}\text { Rata-rata } \\
(2019) \\
(\%)\end{array}$ & $\begin{array}{l}\text { Rata-rata } \\
(2020) \\
(\%)\end{array}$ & $\begin{array}{l}\text { Peningkatan } \\
\text { /Penurunan } \\
(\%)\end{array}$ \\
\hline Return on Asset & 7,923 & 8,082 & 0,159 \\
\hline Return on Equity & 11,011 & 10,710 & $(0,301)$ \\
\hline $\begin{array}{l}\text { Kenaikan } \\
\text { Pertumbuhan } \\
\text { Pendapatan }\end{array}$ & 5,316 & 5,332 & 0,016 \\
\hline Kenaikan & & & \\
\hline & $-35,196$ & $-9,556$ & 25,660 \\
\hline
\end{tabular}




\begin{tabular}{|c|c|c|c|}
\hline $\begin{array}{l}\text { Pertumbuhan } \\
\text { Laba Bersih }\end{array}$ & & & \\
\hline $\begin{array}{l}\text { Kenaikan } \\
\text { Pertumbuhan } \\
\text { Biaya Operasi }\end{array}$ & 6,771 & 4,381 & $(2,630)$ \\
\hline
\end{tabular}

Sumber; Data Diolah Peneliti

Hasil pengolahan data menunjukkan bahwa kinerja keuangan perusahaan dari tahun 2019 ke tahun 2020 meninggkat, hal itu terefleksikan dari peningkatan hasil rata rata tolak ukur yang digunakan, dapat diartikan bahwa meskipum pad masa pandemi perusahaan tetap dapat mempertahankan kinerja keuangannya.

\section{Perspektif Pelangggan}

Perspektif pelanggan menilai kemampuan perusahaan dalan memberikan kepuasan kepada pelanggan melalui pelayan dan hasil produksi. Berdasarkan penelitian terdahulu (Christina \& Sudana, 2013) menggunakan tolak ukur jumlah penghargaan pada perspektif pelanggan.

Tabel 3. Rata-rata Perspektif Pelanggan

\begin{tabular}{llll}
\hline Tolak Ukur & $\begin{array}{l}\text { Rata- } \\
\text { rata } \\
(2019)\end{array}$ & $\begin{array}{l}\text { Rata- } \\
\text { rata } \\
(2020)\end{array}$ & $\begin{array}{l}\text { Peningkatan } \\
\text { Penurunan(dalam } \\
\text { kurung) }\end{array}$ \\
\hline Jumlah & 9,33 & 11,66 & 2.33
\end{tabular}

Penghargaan

Sumber; Data Diolah Peneliti

Hasil penggolahan data menunjukkan bahwa terjadi peningkatan jumlah rata rata penghargaan yang didapat perusahaan dari tahun 2019 ke tahun 2020, hal itu dapat terjadi karena hasil produksi dan pelayanan yang dilakukan perusahaan dapat dirasakan manfaatnya oleh konsumen sehingga jumlah penghargaan yang didapat perusahaan bertambah.

\section{Perspektif Internal Bisnis}

Perspektif pelanggan menilai kemampuan perusahaan dalam berinovasi menghasilkan produkproduk baru seiring dengan kebutuhan konsumen. Berdasarkan penelitian terdahulu(Christina \& Sudana, 2013) jumlah produk baru dijadikan tolak ukur dalam perspektif internal bisnis.

Tabel 4. Rata-rata Perspektif Internal Bisnis

\begin{tabular}{llll}
\hline $\begin{array}{l}\text { Tolak } \\
\text { Ukur }\end{array}$ & $\begin{array}{l}\text { Rata-rata } \\
(2019)\end{array}$ & $\begin{array}{l}\text { Rata-rata } \\
(2020)\end{array}$ & $\begin{array}{l}\text { Peningkatan / } \\
\text { Penurunan(dalam } \\
\text { kurung) }\end{array}$ \\
\hline $\begin{array}{l}\text { Jumlah } \\
\text { Produk } \\
\text { baru }\end{array}$ & 58,83 & 20,16 & $(38,66)$ \\
\hline
\end{tabular}

\section{Sumber; Data Diolah Peneliti}

Data menunujukkan terjadi penurunan jumlah rata-rata produk baru yang dihasilkan perusahaan dari tahun 2019 ke tahun 2020 yang disebabkan perusahaan perusahaan farmasi pada saat ini lebih berfokus ke penyediaan alat-alat kesehatan dan juga penyediaan vaksin.

Perspektif Pertumbuhan dan Pembelajaran

Perspektif ini menilai kemampuan perusahaan untuk dapat mempertahankan kemampuan sumber daya manusia di perusahaan farmasi untuk dapat bertanggung jawab dalam seiap pekerjaan di perusahaan. Berdasarkan penelitian terdahulu yang tolak ukurnya adalah jumlah biaya pelatihan yang dikeluarkan perusahaan.

Tabel 5. Rata-rata Perspektif Pertumbuhan dan

\begin{tabular}{|c|c|c|c|}
\hline \multicolumn{4}{|c|}{ Pembelajaran } \\
\hline $\begin{array}{l}\text { Tolak } \\
\text { Ukur }\end{array}$ & $\begin{array}{l}\text { Rata-rata } \\
\text { (2019) }\end{array}$ & $\begin{array}{l}\text { Rata-rata } \\
(2020)\end{array}$ & $\begin{array}{l}\text { Peningkatan / } \\
\text { Penurunan(dal } \\
\text { am kurung) }\end{array}$ \\
\hline Jumlah & Rp. & Rp. & (Rp. \\
\hline Biaya & 10.612 .785 .3 & 7.731.817.8 & 2.880.967.488 \\
\hline $\begin{array}{l}\text { Pelatih } \\
\text { an }\end{array}$ & 17 & 29 & ) \\
\hline
\end{tabular}

Sumber; Data Diolah Peneliti

Data diatas menunjukkan bahwa terjadi penurunan jumlah biaya pelatihan dari tahun 2019 ke tahun 2020 yang disebabkan perusahaan pada saat pandemi covid 19 sulit untuk melakukan pelatihan secara tatap muka sehingga perusahaan lebih memilih melakukan pelatihan secara online agar kompetensi setiap karyawannya tetap meningkat meski dimasa pandemi. Dengan dilakukannya pelatihan secara online mengakibatkan jumlah biaya pelatihan menurun karena tidak dibutuhkannya biaya yang besar untuk melakukan pelatihan tersebut.

\section{KESIMPULAN}

Berdasarkan pembahasan yang telah diuraikan dapat disimpulkan bahwa penggunaan metode balanced scorecard dalam menilai kinerja perusahaan sangat baik untuk diterapkan dalam usaha pencapaian visi dan misi perusahaan dan juga perbaikan perusahaan kedepannya. Berfokus bukan hanya pada aspek keuangan saja balanced scorecard membantu menyelaraskan tujuan organisasi dengan pihak internal perusahaan secara konsisten. Hasil yang didapatkan menggunakan metode ini dapat membantu pihak manajemen dalam mengambil keputusan untuk mengatasi permasalaahn yang terjadi di perusahaan.

Dalam penilaian kinerja menggunakan metode balanced scorecard di perusahaan sub sektor farmasi sebelum covid 2019 dan semasa covid 2020 didapatkan hasilnya adalah perspektif keuangan mengalami peningkatan, perspektif pelanggan mengalami peningkatan, perspektif internal bisnis mengalami penurunan, persepektif pertumbuhan dan pembelajaran mengalami penurunan.

Berdasarkan hasil diatas pihak manajemen dapat mengambil keputusan bagaimana cara untuk memperbaiki kinerja Perusahaan. Hal yang harus dilakukan pada perspektif keuangan, perusahaan 
farmasi dapat mempertahankan kinerja baiknya bahkan meningkatkannya dengan mengelola keuangan terlebih pada pengelolaan keuangan produksi sehinggga mendapatkan keuntungan sesuai dengan yang diinginkan, perspektif pelanggan, perusahaan dapat lebih memaksimalkan hasil produksi dan pelayanannya dan pada perspektif internal bisnis, dengan lebih banyak berinovasi untuk membuat produk baru, yang seiring dengan kebutuhan konsumen, pada perspektif pertumbuhan dan pembelajaran, dapat lebih memaksimalkan pelatihan yang dilakukan perusahaan agar dapat meningkatkan kemampuan sumber daya manusia perusahaan dalam melakukan tugas dan tanggung jawab perusahaannya sehingga visi misi perusahaan dapat tercapai. Metode ini disarankan agar dapat dapat diterapkan di perusahaan farmasi yang terdaftar di BEI dalam menilai kinerja perusahaanya sehingga dapat memperbaiki kinerja perusahaan selanjutnya.

Keterbatasan dalam penelitian ini adalah penggunaan tolak ukur pada setiap perspektif. Yaitu, ketidak mampuan peneliti dalam menunjukkan hubungan yang kuat antara penggunaan tolak ukur jumlah biaya pelatihan dalam menunjukkan kemampuan perusahaan dalam meningkatkan kompetensi karyawan melalui pelatihan. Selain itu, ketidak mampuan peneliti memberikan informasi mengenai peningkatan return on investment (ROI) pada perspektif keuangan. Disarankan untuk peneliti selanjutnya dapat menggunakan tolak ukur dengan indikator yang lebih luas dan tetap memperhatikan hubungan tolak ukur yang digunakan dengan perspektif balanced scorecard itu sendiri sehingga dapat mempresenetasikan keadaan perusahaan yang sebenarnya.

\section{REFERENSI}

Afandi, P. (2018). Manajemen Sumber Daya Manusia (Teori, Konsep dan. Indikator). Zanafa Publishing.

Atkinson. (2012). Akuntansi Manajemen (Edisi keli). Indeks.

Christina, N. P. Y., \& Sudana, I. P. (2013). Penilaian Kinerja pada PT. Adhi Karya dengan Pendekatan Balanced Scorecard. E-Jurnal Akutansi Universitas Udayana, 3(5), 516-529.

Fahmi. (2017). Manajemen Sumber Daya Manusia Teori dan Aplikasi. Alfabeta.

Hartantik, indah puji. (2014). Buku Praktis Mengembangkan SDM. Laksana.

Kaplan,r \& Norton, D. . (2000). Balanced Scorecard Menerapkan Strategi Menjadi Aksi. Penerbit Erlangga.

Kasmir. (2016). Manajemen Sumber Daya Manusia (Teori dan Praktik) (kedua). Rajawali Pers.

Luis, S. (2007). step by step in cascading balanced scorecard to functional scorecard. PT.Gramedia Pustaka.

Mulyadi. (2009). Terpadu Pengelolaan Kinerja Personel berbasis Balance Scorecard.

Sedarmayanti. (2010). Manajemen Sumber Daya Manusia, Reformasi Birokrasi dan Manajemen Pegawai Negeri Sipil. PT.Refika Aditama.

Veithzal rivai, zainal. (2015). Manajemen Sumber Daya Manusia Untuk Perusahaan: Dari Teori ke Praktik. Rajawali Pers. 